\title{
Evaluasi Geometri dan Perlengkapan Jalan Lingkar Leuwiliang Bogor
}

\author{
(Geometry and Equipment Review of Jalan Lingkar Leuwiliang Bogor) \\ Dzaky Syifaurrahman $^{1}$, Muhammad Fauzan ${ }^{*}$, dan Tri Sudibyo ${ }^{1}$ \\ ${ }^{1}$ Departemen Teknik Sipil dan Lingkungan, Fakultas Teknologi Pertanian, Institut Pertanian \\ Bogor,Jl. Raya Dramaga Kampus IPB \\ *Penulis Korespondensi: fauzanmuhammad@yahoo.com
}

Diterima: 10 September 2018

Disetujui: 22 Maret 2019

\begin{abstract}
Leuwiliang Ring Road had curve, slop and road equipment like signs, markers and street lighting that uncomfortable for drivers. The purpose of this research was to evaluate road geometric based on RSNI T-14-2004 and guidelines no. 038/TBM/1997 and road equipment based on guidelines no. 01/P/BNKT/1991 and SNI 7391: 2008 on Jalan Lingkar Leuwiliang. The results showed that design of geometry and equipment of this road did not conform to Standard. The speed limit used was $50 \mathrm{~km} / \mathrm{h}$. The free side area on the 4th curve was of $3 \mathrm{~m}$ less than Standard $(3.04 \mathrm{~m})$. Slopes of the road were more than 9\% on segment 2 (14.21\%), 4 (10.94\%), $13(9.01 \%), 14(9.19 \%), 26$ (9.20\%), 27 (9.20\%), 28 (9.49\%), $29(12.15 \%)$ and 30 (19.36\%). There were no markers on this road then longitudinal line mark was designed on the road side. Dotted line marks were designed at Sta 0+000 to Sta 0+200 and longitudinal line mark were designed at Sta 0+200 to Sta 0+974.5 on the road divider. There were no street lighting on the 7 th pole to the 22nd pole so the street lighting were designed on that poles using the lamp type SON $100 \mathrm{~W}$ patch to the pole with height of $6 \mathrm{~m}$ from the road surface.

Keywords : free side area, lamp, road, road markings, slope.
\end{abstract}

\section{PENDAHULUAN}

Transportasi merupakan bidang yang berperan penting untuk mempermudah mobilitas barang atau manusia dalam menjalankan roda perekonomian. Transportasi yang digunakan di darat memerlukan lintasan berupa jalan yang dapat menghubungkan titik perpindahan barang atau manusia. Jalan adalah prasarana transportasi darat yang meliputi segala bagian jalan, termasuk bangunan pelengkap dan perlengkapannya yang diperuntukkan bagi lalu lintas, yang berada pada permukaan tanah, di atas permukaan tanah, di bawah permukaan tanah dan/atau air, serta di atas permukaan air, kecuali jalan kereta api, jalan lori, dan jalan kabel (PRI 2006).
Lokasi penelitian berada pada Jalan Lingkar Leuwiliang Kabupaten Bogor. Jalan Lingkar Leuwiliang menghubungkan Terminal Leuwiliang dengan Jalan Raya Leuwiliang. Jalan Lingkar Leuwiliang merupakan jalan kolektor yang digunakan untuk memindahkan sebagian arus kendaraan berat dari jalan arteri melewati Pasar Leuwiliang. Rancangan disain angkutan pembebananjalan kabupaten disesuaikan dengan jalan nasional (Pandey dan Lalamentik 2014).

Kondisi jalan yang kurang baik seperti tikungan tajam tanpa peringatan, jalan tidak dilengkapi dengan marka jalan, jalan bergelombang dan rambu lalu lintas yang kurang memadai serta penerangan jalan kurang memadai dapat memicu terjadi kecelakaan di jalan. Selain karena faktor jalan terdapat beberapa 
faktor yang dapat menimbulkan kecelakaan lalu lintas diantaranya faktor pengemudi, faktor kendaraan dan faktor prasarana jalan (Azizizrahman dkk 2015). Prasarana jalan merupakan faktor yang dapat secara langsung ditangani oleh pemerintah dalam upaya peningkatan keselamatan jalan dengan bentuk perbaikan kualitas jalan (Setyowati dkk 2014).

Penelitian ini bertujuan untuk mengevaluasi lokasi yang memiliki geometri dan perlengkapan jalan yang tidak sesuai aturan standar serta melakukan perbaikan disain geometri dan perlengkapan jalan yang diperlukan sesuai dengan peraturan yang berlaku.

\section{METODE}

Penelitian evaluasi geometri dan perlengkapan Jalan Lingkar Leuwiliang dilakukan pengambilan data di Jalan Lingkar Leuwiliang dan analisis di Departemen Teknik Sipil dan Lingkungan pada bulan April sampai Desember 2017. Penelitian ini menggunakan seperangkat alat ukur berupa Total Station, GPS dan Buku catatan untuk pengukuran eksisting jalan. Selanjutnya data hasil pengukuran diolah dan dianalisis dengan menggunakan software Autocad, Google Earth dan Microsoft Office. Data hasil pengolahan tersebut merupakan data primer.

Penelitian ini juga menggunakan data sekunder. Data sekunder berupa peta RTRW Jabodepunjur dan peraturan - peraturan yang terkait dengan kecepatan, geometri dan pelengkapan jalan. Peraturan peraturan yang digunakan untuk mengukur kecepatan adalah Panduan Survai dan Perhitungan waktu Perjalanan Lalu Lintas No.
001/T/BNKT/1990, evaluasi geometri pada RSNI T-14-2004 (BSN 2004) dan Pedoman No. 038/TBM/1997 (Dirjen BM 1997). Peraturan yang digunakan sebagai batasan evaluasi perlengkapan jalan adalah Pedoman No. 01/P/BNKT/1991 (Dirjen BM 1991) dan SNI 7391:2008 (BSN 2008).

\section{TINJAUAN PUSTAKA}

\section{Alinyemen Horisontal}

Alinyemen horisontal adalah proyeksi sumbu jalan pada bidang horisontal yang terdiri dari garis - garis lurus yang dihubungkan dengan garis garis lengkung. Garis lengkung terdiri atas busur lingkaran dan busur peralihan atau busur lingkaran saja dan busur peralihan saja (Sukirman 1999). Perencanaan alinyemen horisontal ini berfungsi untuk menyeimbangkan gaya sentrifugal yang diterima oleh kendaraan yang berjalan pada kecepatan rencana (Dirjen BM 1997).

Jarak pandangan adalah panjang jalan di depan kendaraan yang masih dapat dilihat dengan jelas yang diukur dari titik kedudukan pengemudi. Keamanan dan kenyamanan pengemudi kendaraan untuk dapat melihat dengan jelas dan menyadari situasinya pada saat mengemudi, sangat tergantung pada jarak yang dapat dilihat dari tempat kedudukannya. Jarak padang berguna untuk menghindari terjadinya kecelakaan yang dapat membahayakan kendaraan akibat adanya obyek baik diam maupun obyek bergerak pada lajur jalannya (Made dan Widianty 2014).

Jarak pandangan terdiri dari dua elemen, yaitu jarak awal reaksi dan jarak pengereman. Jarak awal reaksi adalah jarak yang ditempuh oleh kendaraan sejak pengemudi melihat suatu halangan yang menyebabkan ia 
harus berhenti sampai saat pengemudi menginjak rem. Jarak pengereman adalah jarak yang dibutuhkan untuk menghentikan kendaraan sejak pengemudi menginjak rem sampai kendaraan berhenti (Dirjen BM 1997).

Alinyemen horisontal jalan terbagi menjadi bagian lurus dan bagian tikungan. Bagian lurus merupakan bagian jalan yang tidak memiliki lengkungan pada jalan. Disain bagian lurus jalan ditentukan berdasarkan tingkat kelelahan pengemudi pada saat berkendara, berdasarkan kecepatan rencana melewati bagian lurus jalan. Panjang maksimum yang harus ditempuh dengan kecepatan yang direncanakan dilewati dalam waktu tidak lebih dari 2,5 menit. Bagian tikungan merupakan bagian jalan yang memiliki lengkungan dengan sudut tertentu secara horisontal yang dibuat mengikuti kondisi kontur tanah yang memiliki elevasi sama. Tikungan terdiri dari tiga jenis tikungan yaitu lingkaran F-C (full circle), S-C-S (spiral circle spiral) dan S-S (spiral - spiral) (Hendarsin 2000). Tikungan dengan bentuk lengkung SS (spiral - spiral) memiliki bentuk tikungan yang tajam sehingga berpotensi menyebabkan kecelakaan akibat terjadi penurunan kecepatan.

Tingkat kecelakaan lalu lintas pada tikungan tajam cukup tinggi. Salah satu hal yang dapat menyebabkan kecelakaan adalah ketidaksesuaian disain tikungan dengan standar perencanaan yang berlaku. Hal ini diperburuk dengan perilaku berkendara dengan kecepatan yang tinggi (Purwanto dkk 2015). Kecelakaan yang terjadi disebabkan gaya sentrifugal antara ban dan permukaan jalan. Bila permukaan datar, kendaraan ini akan ditahan oleh "gesekan samping" (side friction) antara ban dan permukaan jalan. (Oglesby dan Hicks 1990)

Daerah bebas samping merupakan daerah pada sisi tikungan yang bebas dari benda apapun sehingga tidak mengganggu jarak pandangan pengemudi. Daerah bebas samping memberikan keluasan atau kebebasan pandangan terhadap tikungan yang dilewati tanpa penghalang. Jarak pandang bebas samping diilustrasikan pada Gambar 1 (Dirjen BM 1997).

Jari - jari tikungan merupakan panjang kelengkungan jalan yang diperlukan agar kendaraan aman melintas dengan kecepatan tertentu. Disain jari - jari tikungan ditentukan antara gesekan melintang antara ban kendaraan dengan permukaan jalan besama - sama dengan komponen berat kendaraan akibat adanya kemiringan melintang lengkung horisontal digunakan untuk mengimbangi gaya sentrifugal (Sukirman 1999).

Pertemuan antara jalan lurus dan menikung perlu disisipkan bagian peralihan yang melengkung dengan jari - jari tetap. Lengkung peralihan dibuat untuk menghindari dari adanya perubahan alinyemen yang mendadak agar melindungi pengguna jalan dari kecelakaan. Kondisi operasional lalu lintas di tikungan memerlukan konsistensi geometrik jalan agar kondisi operasional di tikungan sama dengan dibagian lurus, oleh karena itu diperlukan pelebaran pada tikungan (Dirjen BM 1997).

Bentuk tikungan pada beberapa segmen jalan memerlukan kemiringan melintang atau bisa disebut dengan superelevasi. Superelevasi adalah suatu kemiringan melintang di tikungan yang berfungsi mengimbangi gaya sentrifugal yang diterima kendaraan pada saat berjalan melalui tikungan pada kecepatan tertentu. Superelevasi dibuat memiliki kemiringan yang 
bertahap antara pertemuan jalan lurus dan tikungan. Superelevasi tersebut berfungsi mengimbangi gaya sentrifugal yang diterima kendaraan pada saat berjalan melalui tikungan dengan kecepatan yang direncanakan.

\section{Alinyemen Vertikal}

Alinyemen vertikal adalah perpotongan bidang vertikal dengan bidang permukaan perkerasan jalan melalui sumbu jalan untuk jalan dua lajur dua arah atau tepi dalam masing masing perkerasan untuk jalan dengan median (Sukirman 1999). Pada perencanaan alinyemen vertikal akan ditemui kelandaian positif atau tanjakan dan kelandaian negatif atau turunan yang dilihat dari arah kiri ke kanan. Kombinasi dari kedua kelandaian tersebut akan didapat lengkung cekung dan lengkung cembung. Selain kelandaian positif dan negatif dapat juga ditemui kelanaian 0 (nol) atau datar (Hermansyah et. al 2015).

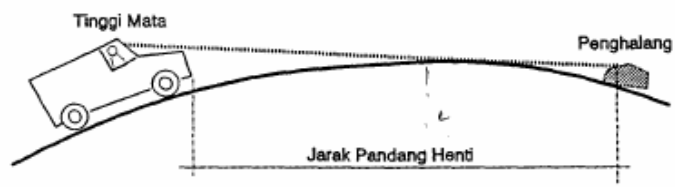

Gambar 3. Lengkung cembung

Kelandaian pada jalan memiliki nilai maksimum yang ditinjau dari kemungkinan kendaraan bergerak terus tanpa kehilangan kecepatan yang berarti. Kelandaian maksimum didasarkan pada kecepatan truk bermuatan penuh yang mampu bergerak dengan penurunan kecepatan tidak lebih dari separuh kecepatan semula tanpa harus menggunakan gigi rendah. Panjang landai kritis atau maksimum adalah landai maksimum yang harus disediakan agar kendaraan dapat mempertahankan kecepatannya sedemikian rupa sehingga penurunan kecepatan tidak lebih dari separuh kecepatan kendaraan. Lama perjalanan yang ditempuh ditetapkan tidak lebih dari 1 menit (Dirjen BM 1997).

Perubahan kelandaian memerlukan peralihan dengan membuat lengkung vertikal. Pembuatan lengkung vertikal bertujuan untuk megurangi goncangan akibat perubahan kelandaian dan menyediakan jarak pandang henti. Lengkung vertikal terbagi menjadi dua jenis, yaitu lengkung vertikal cekung dan lengkung vertikal cembung. Panjang lengkung vertikal didasarkan pada penampilan, kenyamanan dan jarak pandang yang diilustrasikan pada Gambar 3 (Dirjen BM 1997) dan Gambar 4 (Dirjen BM 1997).

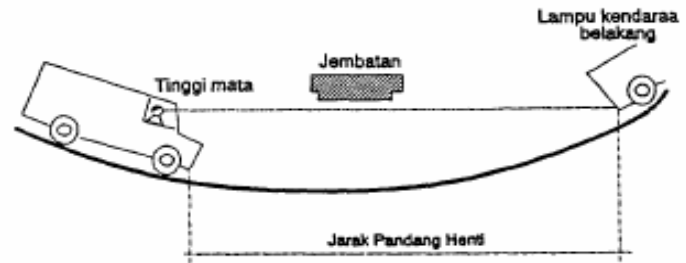

Gambar 4. Lengkung cekung

Lengkung vertikal perlu direncanakan untuk menyediakan jarak pandang henti dan mengurangi goncangan akibat perubahan kelandaian. Lengkung vertikal ini harus direncanakan pada setiap perubahan kelandaian. Panjang lengkung vertikal merupakan panjang bagian yang melengkung pada jalan yang dilihat tegak lurus tanpa mengikuti bentuk lengkung pada jalan. Panjang lengkung vertikal diilustrasikan pada Gambar 5 (Dirjen BM 1997).

\section{Koordinasi Alinyemen}

Alinyemen vertikal, alinyemen horizontal, dan potongan melintang jalan adalah elemen - elemen jalan sebagai keluaran perencanaan yang harus dikoordinasikan sedemikian 
sehingga menghasilkan suatu bentuk jalan yang baik dalam arti memudahkan pengemudi mengemudikan kendaraannya dengan aman dan nyaman. Bentuk kesatuan ketiga elemen jalan tersebut diharapkan dapat memberikan kesan atau petunjuk kepada pengemudi akan bentuk jalan yang akan dilalui di depannya sehingga pengemudi dapat melakukan antisipasi lebih awal (Dirjen BM 1997). Koordinasi alinyemen yang baik adalah tidak terdapat daerah pada jalan yang tidak terlihat oleh pengemudi sehingga pengemudi dapat melihat kondisi di depannya.

Koordinasi alinyemen vertikal dan alinyemen horizontal harus memenuhi ketentuan sebagai berikut: (1) alinyemen horizontal sebaiknya berimpit dengan alinyemen vertikal, dan alinyemen horizontal lebih panjang sedikit melingkupi alinyemen vertikal, (2) tikungan yang tajam pada bagian bawah lengkung vertikal cekung atau pada bagian atas lengkung vertikal cembung harus dihindarkan, (3) lengkung vertikal cekung pada kelandaian jalan yang lurus dan panjang harus dihindarkan, (4) dua atau lebih lengkung vertikal dalam satu lengkung horizontal harus dihindarkan, dan (5) tikungan yang tajam di antara 2 bagian jalan yang lurus dan panjang harus dihindarkan.

\section{Perlengkapan Jalan}

Fasilitas perlengkapan jalan memberi informasi kepada pengguna jalan tentang peraturan dan petunjuk yang diperlukan untuk mencapai arus lalu lintas yang selamat, seragam dan beroperasi dengan efisien. Tujuan dari pemasangan perlengkapan jalan adalah untuk meningkatkan keselamatan jalan dan menyediakan pergerakan yang teratur terhadap pengguna jalan. Perlengkapan jalan sesuai panduan penempatan fasilitas perlengkapan jalan berupa marka jalan, rambu-rambu lalu lintas, alat pemberi isyarat lalu lintas, dan fasilitas penerangan jalan.

\section{Marka Jalan}

Marka jalan berfungsi untuk menyediakan petunjuk dan informasi terhadap pengguna jalan. Informasi yang disampaikan berupa peraturan, petunjuk, atau peringatan yang tidak dapat disampaikan oleh alat kontrol lalu lintas yang lain (Utami dan Sukirman 2016). Marka jalan terdiri dari marka membujur, marka melintang, marka serong dan marka lambang.

Marka membujur terdiri atas marka membujur garis utuh, marka membujur garis putus - putus, dan marka membujur garis ganda (Utami dan Sukirman 2016). Marka membujur berupa garis utuh berfungsi sebagai larangan bagi kendaraan melintasi garis tersebut. Marka membujur berupa satu garis utuh juga dipergunakan untuk menandakan tepi jalur lalu lintas. Marka membujur berupa garis putusputus berfungsi untuk mengarahkan lalu lintas dan memperingatkan akan ada marka membujur berupa garis utuh di depan dan pembatas jalur pada jalan 2 (dua) arah.

Marka membujur pada jalan jalan tertentu dilengkapi dengan paku jalan. Paku jalan berfungsi sebagai reflektor marka jalan khususnya pada cuaca gelap dan malam hari. Paku jalan dengan pemantul cahaya berwarna kuning digunakan untuk pemisah jalur atau lajur lalu lintas. Paku jalan dengan pemantul cahaya berwarna merah ditempatkan pada garis batas di sisi jalan. Paku jalan dengan pemantul berwarna putih ditempatkan pada garis batas sisi kanan jalan. Paku jalan dapat ditempatkan pada batas tepi jalur lalu lintas, marka membujur berupa garis 
putus-putus sebagai tanda peringatan, sumbu jalan sebagai pemisah jalur, marka membujur berupa garis utuh sebagai pemisah lajur bus, marka lambang berupa chevron dan pulau lalu lintas.

Marka melintang dibedakan atas marka melintang garis utuh dan marka melintang garis ganda putus-putus. Marka melintang berupa garis utuh menyatakan batas berhenti kendaraan yang diwajibkan oleh alat pemberi isyarat lalu lintas atau rambu larangan berjalan terus. Marka melintang berupa garis ganda putus-putus menyatakan batas berhenti kendaraan sewaktu mendahulukan kendaran lain. Marka serong berupa garis utuh memiliki arti dilarang dilintasi kendaraan. Marka serong yang dibatasi dengan rangka garis utuh digunakan untuk menyatakan daerah yang tidak boleh dimasuki kendaraan, pemberitahuan awal sudah mendekati pulau lalu lintas, dan pemberitahuan awal atau akhir pemisah jalan, pengarah lalu lintas dan pulau lalu lintas. Marka lambang berfungsi untuk mengulangi maksud rambu-rambu lalu lintas atau untuk memberitahu pengguna jalan yang tidak dinyatakan dengan rambu lalu lintas jalan yang tanda lambangnya berupa panah, segitiga, dan tulisan.

\section{Fasilitas Penerangan Jalan}

Lampu penerangan jalan merupakan salah satu bagian dari bangunan pelengkap jalan yang dapat diletakkan atau dipasang di kiri/ kanan jalan dan atau di tengah (bagian median jalan) yang digunakan untuk menerangi jalan maupun lingkungan di sekitar jalan yang diperlukan termasuk persimpangan jalan, jalan layang, jembatan dan jalan di bawah tanah (Utami dan Sukirman 2016). Pencahayaan pada ruas jalan memiliki ketentuan yang didasarkan pada kuat pencahayaan normal (iluminasi) dan luminasi pada penggunaan jalan disaat situasi jalan dalam kondisi gelap.

Lampu penerangan yang digunakan memiliki rumah lampu penerangan (lantern) yang diklasifikasikan berdasaran menurut tingkat perindungan atau disebut IP (index of protection). IP memiliki dua angka dalam pengklasifikasian jenis perlindungan. Angka yang pertama menyatakan indek perlindungan terhadap debu/ benda dan angka yang kedua menyatakan indek perlindungan terhadap air. Sistem IP merupakan penggolongan yang lebih awal terhadap penggunaan peralatan yang tahan hujan dan sebagainya, dan ditandai dengan lambang. Semakin tinggi indek perlindungan (IP), semakin baik Standar perlindungannya (BSN 2008). Pada umumnya, indek perlindungan (IP) yang sering dipakai untuk klasifikasi lampu penerangan adalah : IP 23, IP 24, IP 25, IP 54, IP 55, IP 64, IP 65, dan IP 66.

Penempatan lampu penerangan jalan harus direncanakan aman bagi pengguna jalan. Pencahayaan yang lebih tinggi di area tikungan atau persimpangan, dibanding pada bagian jalan yang lurus. Arah dan petunjuk (guide) yang jelas bagi pengguna jalan dan pejalan kaki. Sistem penempatan parsial, lampu penerangan jalan harus memberikan adaptasi yang baik bagi penglihatan pengendara, sehingga efek kesilauan dan ketidaknyamanan penglihatan dapat dikurangi. Daerahdaerah atau kondisi dimana median sangat lebar $(>10 \mathrm{~m})$ atau pada jalan dimana jumlah lajur sangat banyak ( $>4$ lajur setiap arah) perlu dipertimbangkan dengan pemilihan penempatan lampu penerangan jalan kombinasi. 


\section{Kecepatan Kendaraan}

Kecepatan adalah informasi
waktu tempuh kendaraan yang
melewati suatu jalur tententu.
Informasi tersebut dapat digunakan
sebagai pertimbangan perencanaan
dalam menentukan ruas jalan yang
akan dibuat. Kecepatan yang dipilih
adalah kecepatan yang sesuai dengan
kondisi dan fungsi jalan yang
diharapkan (Sukirman 1999).

Kecepatan yang diinginkan pengemudi akan tergantung pada persepsi pengemudi dalam menilai semua faktor pengaruh tersebut (Sulistio 1997). Kecepatan adalah tingkat pergerakan lalu-lintas atau kendaraan tertentu yang sering dinyatakan dalam kilometer per jam. Kecepatan rata-rata dihitung berdasarkan jarak perjalanan dibagi waktu perjalanan pada jalan tertentu. Kecepatan ini dapat ditentukan melalui pengukuran waktu perjalanan dan hambatan (Dirjen BM 1990). Kecepatan kendaraan dapat menyebabkan kerusakan pada jalan dikarena faktor loading time atau waktu pengangkutan sehingga dapat digunakan untuk menentukan umur jalan yang direncanakan (Nugroho 2012).

Kecepatan berpengaruh dalam kecelakaan lalu lintas, terutama saat berada di tikungan. Jumlah kecelakaan di tikungan jalan 1,5 hingga 4 kali lebih banyak dari pada di bagian lurus jalan. Kematian dan kerusakan akibat kecelakaan lalu lintas yang terjadi di tikungan berkisar 25\% hingga 30\% (Manggala dkk 2015).Kecepatan kendaraan diperlukan pengatuaran pada beberapa aktivitas tertentu. Aktivitas aktivitas yang perlu diperhatikan adalah penentuan peraturan lalu-lintas dan penempatan alat-alat pengatur, studi untuk mengatasi tingkat kecelakaan yang tinggi pada lokasilokasi tertentu dimana dapat ditentukan korelasi antara kecepatan dan kecelakaan, evaluasi tingkat perbaikan lalu-lintas dan analisa daerah kritis yang banyak terjadi keluhan. Selain itu juga, penentuan elemen-elemen perencanaan geometrik jalan, penentuan tingkat keperluan penegakan hukum dan evaluasi ekonomi seperti menghitung biaya operasi kendaraan dari peningkatan jalan atau pengaturan lalu-lintas. Penentuan rute yang efisien untuk arus lalu-lintas, identifikasi lokasi-lokasi kemacetan lalu-lintas dan studi perencanaan transportasi seperti pada proses alokasi lalu-lintas juga perlu diperhatikan. (Dirjen BM 1990).

\section{HASIL DAN PEMBAHASAN}

\section{Data Teknis Jalan}

Jalan Lingkar Leuwiliang merupakan jenis jalan kolektor yang mengalihkan sebagian arus lalu lintas kendaraan yang melalui Pasar Leuwiliang. Jalan Lingkar Leuwiliang memiliki panjang jalur $\pm 2.5 \mathrm{~km}$ yang diukur dari simpang tiga Jalan Lingkar Leuwiliang sampai Terminal Bus Leuwiliang melewati TPA Galuga. Jalan Lingkar Leuwiliang juga digunakan sebagai jalur lalu - lintas mobil truk sampah TPA Galuga. Jalan Lingkar Leuwiliang berpotongan dengan empat jalan yaitu Jalan Cijunjung dan Jalan Raya Karehkel, sedangkan dua jalan lainnya tidak ditemukan nama jalannya.

Jalan tersebut termasuk kedalam jalan dengan 1 jalur - 2 lajur - 2 arah. Panjang jalur adalah $1035.57 \mathrm{~m}$ yang diukur dari persimpangan Jalan Lingkar Leuwiliang sampai persimpangan Galuga. Lebar jalan pada bagian lurus $5 \mathrm{~m}$ dan lebar jalan pada tikungan $6 \mathrm{~m}$. Pada Jalan Lingkar Leuwiliang yang menjadi objek penelitian terdapat empat buah 
tikungan dan hasil evaluasi geometrik yang dilakukan tersaji pada Tabel 1.

Tabel 1. Data lokasi tikungan

\begin{tabular}{cc}
$\begin{array}{c}\text { Tikungan } \\
\text { ke- }\end{array}$ & Lokasi \\
\hline 1 & Sta $0+533.45-0+578.99$ \\
2 & Sta $0+624.53-0+732.63$ \\
3 & Sta $0+736.61-0+783.75$ \\
4 & Sta $0+871.22-0+961.95$ \\
\hline
\end{tabular}

Jalan Lingkar Leuwiliang yang menjadi objek penelitian terhadap alinyemen vertikal yaitu jalan yang berbentuk lengkung cembung pada Sta 0+190.02 sampai Sta $1+030.42$. Kelandaian rata - rata pada setiap kemiringan adalah $7.38 \%$. Lokasi jalan berada pada perbukitan dengan titik puncak 248 mdpl dan titik terendah 218 mdpl.

Kondisi perlengkapan jalan yang terdapat di Jalan Lingkar Leuwiliang kurang memadai. Perlengkapan jalan yang kurang memadai seperti tidak terdapat marka jalan sepanjang Jalan Lingkar Leuwiliang dan penerangan yang tedapat enam buah pada permulaan jalan yang menjadi objek penelitian.

\section{Kecepatan Kendaraan}

Kecepatan kendaraan yang diatur dipengaruhi oleh kondisi kepadatan penduduk dan aktivitas - aktivitas yang terjadi disekitar jalan. Jalan Lingkar Leuwiliang menurut peta RTRW Jabodetabekpunjur (Bakosurtanal 2007) dan Peraturan Metri Perhubungan Republik Indonesia Nomor PM 111 Tahun 2015 (KemenHub 2015) berada pada wilayah pemukiman rendah penduduk dengan 1 (satu) lajur, tidak berada pada kawasan pemukiman yang padat, tidak pada daerah industri dan tidak pada daerah bisnis, sehingga kecepatan yang digunakan sebagai batas kecepatan maksimum dalam penelitian ini adalah $50 \mathrm{~km} / \mathrm{jam}$.

Pengukuran kecepatan dilakukan selama satu hari yaitu pada hari Sabtu, 2 Desember 2017 selama 12 jam dari pukul 7.00 sampai pukul 19.00. Hasil dari pengukur kecepatan tersebut diangap sama pada hari - hari yang lainnya. Berdasarkan grafik pada Gambar 16 kecepatan tinggi terjadi pada pukul 14.00 sebesar 60.92 $\mathrm{km} / \mathrm{jam}$. Kondisi jalan pada kecepatan tersebut terlihat lengang sehingga pengendara dapat menjalankan

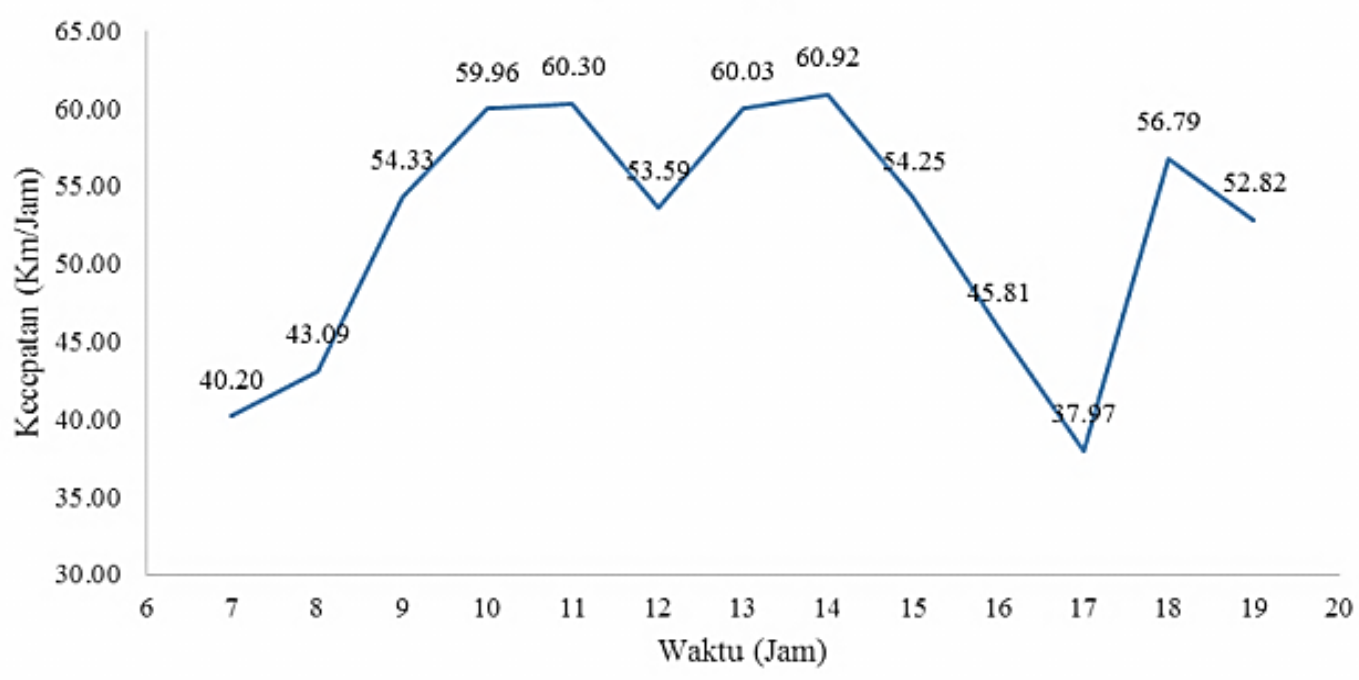

Gambar 16. Kecepatan kendaraan per jam 
kendaraan dengan kecepatan tersebut. Kecepatan terendah terjadi pada pukul 17.00 sebesar $37.97 \mathrm{~km} / \mathrm{jam}$. Kondisi jalan pada pukul 17.00 terlihat ramai sehingga pengemudi tidak dapat melaju dengan cepat.

Kecepatan pengemudi yang melintasi Jalan Lingkar Leuwiliang pada jam terentu melebihi batas kecepatan yang diatur. Kondisi tersebut terjadi pada pukul 09.00 sampai pukul 16.00 dan pada pukul 18.00 sampai pukul 19.00. Perigatan pembatasan kecepatan diperlukan pada Jalan Lingkar Leuwiliang. Peringatan tersebut berupa rambu pembatasan kecepatan maksimum $50 \mathrm{~km} / \mathrm{jam}$ yang dipasang pada permulaan Jalan Lingkar Leuwiliang. Sehingga pengemudi telah dihimbau untuk melakukan pembatasan kecepatan kendaraan yang dikemudikan.

\section{Geometrik Jalan}

Analisa alinyemen horisontal pada Jalan Lingkar Leuwiliang dilakukan berdasarkan batas kecepatan yang diatur dan kecepatan pengemudi pada saat melewati tikungan. Tikungan pada Jalan Lingkar Leuwiliang yang dilakukan analisis terdapat 4 tikungan. Tikungan ke-1 sampai tikungan ke-3 merupakan tikungan gabungan balik dengan clothoide. Clothoide adalah sisipan bagian lurus pada tikungan ganda balik dan tikungan ganda searah. Tikungan ke-4 merupakan tikungan tunggal dengan tipe full circle (fc).

Komponen analisis jari - jari minimum tikungan terdiri dari kecepatan rencana, superelevasi maksimum, dan gaya gesek ban dengan jalan. Kecepatan yang menjadi acuan diatur dari $30 \mathrm{~km} / \mathrm{jam}$ sampai 70 $\mathrm{km} / \mathrm{jam}$. Tikungan dengan tipe $\mathrm{fc}$ memiliki nilai superelevasi yang linier dengan jalan lurus sebesar $2 \%$. Nilai gaya gesek ban dengan jalan yang digunakan adalah 0.14. Nilai jari - jari minimum tersaji pada Tabel 3.

Berdasarkan Tabel 3 pada kecepatan $50 \mathrm{~km} / \mathrm{jam}$ semua jari - jari tikungan ke-1 sampai ke-4 berada diatas nilai minimum yang dibutuhkan sehingga pengendara aman melintasi tikungan - tikungan tersebut. Pengendara yang memacu kendaraanya melebihi kecepatan yang diatur dapat berbahaya. Kecepatan $60.92 \mathrm{~km} / \mathrm{jam}$ dapat berbahaya ketika melintasi tikungan ke-1. Tikungan ke-1 memiliki jari - jari yang tidak memenuhi syarat pada kecepatan $60 \mathrm{~km} / \mathrm{jam}$. Nilai jari jari minimum pada kecepatan 60 $\mathrm{km} / \mathrm{jam}$ adalah $101.24 \mathrm{~m}$ sedangkan nilai jari - jari pada tikungan ke-1 adalah $80.97 \mathrm{~m}$.

Tabel 3. Data hasil evaluasi alinyemen horisontal

\begin{tabular}{|c|c|c|c|c|c|c|}
\hline \multirow[t]{2}{*}{$\begin{array}{c}\text { Tikungan } \\
\text { Ke- }\end{array}$} & \multirow[t]{2}{*}{ Tipe } & \multirow[t]{2}{*}{$\begin{array}{c}\text { Kecepatan } \\
\text { Rencana, } \\
\text { Vr } \\
(\mathbf{k m} / \mathbf{j a m})\end{array}$} & \multicolumn{2}{|c|}{$\begin{array}{c}\text { Jari - jari } \\
\text { Minimum } \\
\text { Tikungan, R } \\
\text { (m) }\end{array}$} & \multicolumn{2}{|c|}{$\begin{array}{c}\text { Daerah } \\
\text { Bebas } \\
\text { Samping, E } \\
\text { (m) }\end{array}$} \\
\hline & & & Eks & Rek & Eks & Rek \\
\hline \multirow{5}{*}{1} & \multirow{5}{*}{$\mathrm{fc}$} & 30 & \multirow{5}{*}{80.97} & 30 & \multirow{5}{*}{ - } & 1.27 \\
\hline & & 40 & & 50 & & 2.68 \\
\hline & & 50 & & 80 & & 4.9 \\
\hline & & 60 & & 110 & & 8.13 \\
\hline & & 70 & & 160 & & 12.59 \\
\hline \multirow{5}{*}{2} & \multirow{5}{*}{$\mathrm{fc}$} & 30 & \multirow{5}{*}{233.9} & 30 & \multirow{5}{*}{-} & 0.44 \\
\hline & & 40 & & 50 & & 0.93 \\
\hline & & 50 & & 80 & & 1.71 \\
\hline & & 60 & & 110 & & 2.86 \\
\hline & & 70 & & 160 & & 4.46 \\
\hline \multirow{5}{*}{3} & \multirow{5}{*}{$\mathrm{fc}$} & 30 & \multirow{5}{*}{347.41} & 30 & \multirow{5}{*}{4} & 0.3 \\
\hline & & 40 & & 50 & & 0.63 \\
\hline & & 50 & & 80 & & 1.15 \\
\hline & & 60 & & 110 & & 1.93 \\
\hline & & 70 & & 160 & & 3.01 \\
\hline \multirow{5}{*}{4} & \multirow{5}{*}{$\mathrm{fc}$} & 30 & \multirow{5}{*}{131.1} & 30 & \multirow{5}{*}{3} & 0.79 \\
\hline & & 40 & & 50 & & 1.66 \\
\hline & & 50 & & 80 & & 3.04 \\
\hline & & 60 & & 110 & & 5.08 \\
\hline & & 70 & & 160 & & 7.91 \\
\hline
\end{tabular}

\footnotetext{
Keterangan : Eks (Eksisting), Rek (Rekomendasi)
} 
Daerah bebas samping merupakan daerah tanpa penghalang yang diperlukan pada suatu tikungan agar pengemudi dengan mudah melihat kondisi lalu lintas di depannya pada suatu tikungan. Komponen analisis daerah bebas samping menggunakan data pengukuran di lapangan dan data analisi. Data pengukura di lapangan berupa kecepatan kendaraan rencana dan kecepatan kendaraan aktual. Data analisi berupa perhitungan jarak pandang kendaraan dan jari - jari tikungan yang terukur. Hasil analisa daerah bebas samping terdiri dari empat buah tikungan. Hasil tersebu tersaji pada Tabel 3 yang diukur pada kecepatan $30 \mathrm{~km} / \mathrm{jam}$ sampai 70 $\mathrm{km} / \mathrm{jam}$.

Berdasarkan hasil pengukuran pada Tabel 3 terlihat bahwa daerah bebas samping pada tikungan ke-1 dan ke-2 tidak memiliki penghalang pada daerah tikungannya. Hal tersebut karena daerah pada sisi tikungan ke-1 dan ke-2 berupa lahan kosong yang sudah tidak berbukit. Pengendara yang melaju dengan kecepatan maksimum yang ditentukan dapat aman melalui tikungan ke1 sampai tikungan ke-3. Pada tikungan ke-4 pengemudi harus menurunkan sedikit kecepatannya dibawah $50 \mathrm{Km} / \mathrm{jam}$. Karena daerah bebas samping pada tikungan ke-4 tidak memenuhi kriteria jarak pandang sesuai pedoman sebesar $3.04 \mathrm{~m}$. Selisih sebesar 0.04 tersebut akan mengganggu pandangan pengemudi ketika kendaraan muatan dalam kondisi muatan penuh.

Kecepatan pengemudi yang melintas pada Jalan Lingkar Leuwiliang pada waktu tertentu dapat melebihi batas kecepatan. Berdasarkan Tabel 3, pengemudi dapat aman melewati tikungan ke-1 sampai tikungan ke-3 dengan aman. Kecepatan tersebut dapat membahayakan pengemudi ketika melewati tikungan ke-4. Kecepatan tertinggi sebesar 60.92 $\mathrm{km} / \mathrm{jam}$ dapat membahayakan pengemudi karena daerah bebas samping yang disediakan harus lebih dari $5.08 \mathrm{~m}$.

Tabel 4. Clothoide dan perbandingan jari - jari tikungan gabungan

\begin{tabular}{ccc}
\hline Tikungan & R/R & $\begin{array}{c}\text { Clothoide } \\
(\mathbf{m})\end{array}$ \\
\hline $1-2$ & 0.346 & 45.54 \\
$2-3$ & 0.673 & 3.98 \\
\hline
\end{tabular}

Tikungan gabungan balik pada Jalan Lingkar Leuwiliang terdapat bagian lurus atau clothoide. Clothoide diperlukan apabila nilai perbadingan jari - jari tikungan gabungan kurang dari 0.677. Panjang minimum clothoide pada tikungan ganda searah adalah 20 $\mathrm{m}$ dan tikungan ganda balik $30 \mathrm{~m}$ (Suwardo dan Haryanto 2016). Tikungan gabungan $1-2$ dan $2-3$ memiliki nilai $\mathrm{R} / \mathrm{R}$ kurang dari 0.677 sehingga memerlukan clothoide. Berdasarkan hasil pengukuran di lapangan pada Tabel 4 terdapat clothoide tikungan gabungan balik 1 2 sepanjang $45.54 \mathrm{~m}$ dan tikungan gabungan balik $2-3$ sepanjang $3.98 \mathrm{~m}$. Panjang clothoide tikungan gabungan balik $1-2$ sudah sesuai dengan pedoman yang berlaku. Sedangkan panjang clothoide tikungan gabungan balik 2 - 3 memiliki panjang yang tidak sesuai dengan pedoman yang berlaku sehingga perlu dilakukan perubahan alinyemen pada bagian tersebut.

Alinyemen vertikal merupakan proyeksi memanjang dari jalan yang dilihat secara vertikal. Alinyemen vertikal Jalan Lingkar Leuwiliang berbentuk lengkung cembung pada Sta $0+190.02$ sampai Sta 1+ 030.42. Kelandaian rata - rata pada setiap kemiringan adalah $7.38 \%$. Lokasi jalan 
berada pada perbukitan dengan titik puncak 248 mdpl dan titik terendah 218 mdpl. Alinyemen vertikal terbagi menjadi dua, yaitu landai menanjak dan landai menurun.

Kelandaian pada jalan didisain untuk memperthankan kecepatan kendaraan tanpa harus kehilangan kecepatan yang berarti. Kelandaian maksimum yang digunakan untuk kecepatan $50 \mathrm{~km} / \mathrm{jam}$ adalah $9 \%$. Pembatasan tersebu digunakan sebagai acuan kecepatan maksimum kendaraan yang diatur.Kelandaian pada Jalan lingkar Leuwiliang terbagi dua, yaitu landai positif berupa tanjakan dan landai negatif berupa turunan.

Panjang kritis merupakan panjang maksimum yang diperukan pada suatu kelandaian jalan. Panjang kritis yang ditinjau pada kelandaian jalan menggunakan acuan kecepatan 60 $\mathrm{km} / \mathrm{jam}$. Hal tersebut didasarkan pada nominal acuan yang terdapat pada Tata Cara Perencanaan Geometrik Jalan Antar Kota (Dirjen BM 1997). Analisa panjang kritis dilakukan pada kecepatan tertinggi di lapangan. Setiap segmen memiliki kelandaian yang bervariasi. Tinjauan Panjang kritis disesuikan dengan kelandaian yang ada. Jika kelandaian kurang dari $4 \%$ maka acuan yang digunakan adalah kelandaian $4 \%$ dengan panjang $320 \mathrm{~m}$. Jika kelandaian lebih dari $10 \%$ makan tinjauan panjang kritis menggunakan kelandaian $10 \%$ dengan panjang $80 \mathrm{~m}$.

Tabel 5. Kelandaian dan panjang kritis tanjakan

\begin{tabular}{ccccc}
\hline Segmen & $\begin{array}{c}\text { Panjang } \\
\text { Landai } \\
(\mathbf{m})\end{array}$ & $\begin{array}{c}\text { Landai } \\
(\boldsymbol{\%})\end{array}$ & $\begin{array}{c}\text { Landai } \\
\text { Acuan } \\
(\boldsymbol{\%})\end{array}$ & $\begin{array}{c}\text { Panjang } \\
\text { Kritis } \\
(\mathbf{m})\end{array}$ \\
\hline 1 & 20.11 & 3.48 & 4 & 320 \\
2 & 32.69 & 14.21 & 10 & 80 \\
3 & 43.86 & 8.14 & 9 & 90 \\
4 & 14.07 & 10.94 & 10 & 80 \\
5 & 18.64 & 8.07 & 9 & 90 \\
\hline
\end{tabular}

\begin{tabular}{ccccc}
\hline 6 & 19.5 & 6.53 & 7 & 120 \\
7 & 9.99 & 3.00 & 4 & 320 \\
8 & 13.78 & 1.16 & 4 & 320 \\
9 & 26.30 & 3.88 & 4 & 320 \\
10 & 20.52 & 6.25 & 7 & 120 \\
11 & 40.88 & 8.12 & 9 & 90 \\
12 & 20.54 & 8.11 & 9 & 90 \\
13 & 18.49 & 9.01 & 10 & 80 \\
14 & 43.14 & 9.19 & 10 & 80 \\
15 & 35.57 & 6.00 & 6 & 160 \\
16 & 28.13 & 3.31 & 4 & 320 \\
\hline
\end{tabular}

Berdasarkan Tabel 5 terdapat beberapa landai jalan pada tanjakan yang melebihi nilai batas kelandaian $9 \%$ dengan batas kecepatan $50 \mathrm{~km} / \mathrm{jam}$. Landai tersebut berada pada segmen 2 (14.21\%), segmen 4 (10.94\%), segmen $13(9.01 \%)$ dan segmen 14 (9.19\%). kelandaian yang melebihi batas maksimum tersebut dapat menyebabkan berkurangnya kecepatan yang berarti pada kendaraan acuan berupa kendaraan bermuatan penuh sehingga dapat menimbulkan perlambatan pada segmen jalan tertentu pada posisi menanjak. Perlambatan yang terjadi berpotensi menyebabkan antrian pada tanjakan sehingga dapat memperlambat laju kendaraan yang melintas. Kelandaian pada posisi turunan yang melebihi batas maksimum dapat membahayakan pengemudi karena beban kendaraan begeser ke depan sehingga kecepatan akan bertambah

Panjang kritis pada Tabel 5 menunjukkan bahwa panjang landai pada masing - masing segmen berada pada batas maksimum yang diatur. Perbedaan acuan nilai kelandaian dikarenakan panjang kritis pada masing - masing acuan kelandaian memiliki nilai yang berbeda. Terdapat nilai kelandaian yang kurang dari $4 \%$ yaitu pada segmen $1(3.48 \%)$, segmen 7 (3\%), segmen $8(1.16 \%)$, segmen 9 
(3.88\%), dan segmen $16 \quad(3.31 \%)$ dengan panjang masing - masing segmen $20.11 \mathrm{~m}, 9.99 \mathrm{~m}, 13.78 \mathrm{~m}$, $26.30 \mathrm{~m}$ dan $28.13 \mathrm{~m}$. Nilai kelandaian yang kurang dari $4 \%$ dianggap tidak mengganggu pengurangan kecepatan kendaraan. Kelandaian yang melebih $10 \%$ yaitu pada segmen $2(14.21 \%)$ dengan panjang $32.69 \mathrm{~m}$ dan segmen 4 (10.94\%) dengan panjang dan $14.07 \mathrm{~m}$.

Tabel 6. Kelandaian dan panjang kritis turunan

\begin{tabular}{|c|c|c|c|c|c|}
\hline $\begin{array}{c}\text { Segme } \\
\mathbf{n}\end{array}$ & $\begin{array}{c}\text { Panjang } \\
\text { Landai } \\
\text { (m) }\end{array}$ & $\begin{array}{c}\text { Landai } \\
(\%)\end{array}$ & & $\begin{array}{c}\text { Landa } \\
\text { i } \\
\text { Acuan } \\
(\%)\end{array}$ & $\begin{array}{c}\text { Panjan } \\
\text { g Kritis } \\
\text { (m) }\end{array}$ \\
\hline 18 & 27.74 & -2.78 & & 4 & 320 \\
\hline 19 & 27.92 & -5.85 & 6 & 160 & \\
\hline 20 & 28.19 & -6.83 & 7 & 120 & \\
\hline 21 & 42.59 & -5.74 & 6 & 160 & \\
\hline 22 & 39.89 & -4.09 & 5 & 210 & \\
\hline 23 & 33.08 & -4.96 & 5 & 210 & \\
\hline 24 & 48.20 & -6.57 & 7 & 120 & \\
\hline 25 & 25.17 & -5.29 & 6 & 160 & \\
\hline 26 & 43.88 & -9.20 & $\begin{array}{l}1 \\
0\end{array}$ & 80 & \\
\hline 27 & 32.12 & -9.20 & $\begin{array}{l}1 \\
0\end{array}$ & 80 & \\
\hline 28 & 9.84 & -9.49 & $\begin{array}{l}1 \\
0\end{array}$ & 80 & \\
\hline 29 & 22.39 & -12.15 & $\begin{array}{l}1 \\
0\end{array}$ & 80 & \\
\hline 30 & 10.47 & -19.36 & $\begin{array}{l}1 \\
0\end{array}$ & 80 & \\
\hline 31 & 17.67 & -9.55 & $\begin{array}{l}1 \\
0\end{array}$ & 80 & \\
\hline
\end{tabular}

Berdasarkan Tabel 6 tinjauan kelandaian turunan terdapat beberapa landai jalan pada turunan yang melebihi nilai batas kelandaian $9 \%$ dengan batas kecepatan $50 \mathrm{~km} / \mathrm{jam}$. Landai tersebut berada pada segmen 26 $(9.20 \%)$, segmen $27(9.20 \%)$, segmen 28 (9.49\%), segmen 29 (12.15\%), segmen $30(19.36 \%)$ dan segmen 31 $(9.55 \%)$. kelandaian yang melebihi batas maksimum dapat membayakan pengemudi karena beban kendaraan begeser ke depan sehingga kecepatan akan bertambah. Kelandaian pada posisi tanjakan dapat menebabkan melambatnya kendaraan acuan berupa kendaraan bermuatan penuh pada posisi tanjakan sehingga dapat menimbulkan perlambatan.

Perlambatan yang terjadi berpotensi menyebabkan antrian yang dapat memperlabat laju kendaraan.

Panjang kritis pada Tabel 6 menunjukan bahwa panjang landai pada masing - masing segmen berada pada batas maksimum yang diatur. Perbedaan acuan nilai kelandaian dikarenakan panjang kritis pada masing-masing acuan kelandaian memiliki nilai yang berbeda.

Terdapat nilai kelandaian yang kurang dari $4 \%$ yaitu pada segmen 18 dengan nilai kelandaian $2.78 \%$. Nilai kelandaian yang kurang dari $4 \%$ dianggap tidak mengganggu pengurangan kecepatan kendaraan. Kelandaian yang melebih $10 \%$ yaitu pada segmen $26(9.20 \%)$, segmen 27 (9.20\%), segmen $28(9.49 \%)$, segmen $29(12.15 \%)$, segmen $30(19.36 \%)$ dan segmen $31(9.55 \%)$.

Panjang lengkung vertikal harus disediakan pada setiap lokasi yang mengalami perubahan kelandaian. Perubahan akibat perbedaan kelandaian dapat menimbulkan guncangan. Kecepatan pengemudi mempengaruhi jarak pandang henti kendaraan. Berdasarkan data hasil pengukuran, kelandaian pada posisi tanjakan adalah $6.84 \%$ dan kelandaian pada posisi turunan adalah $7.93 \%$. Panjang lengkung dihitung dari STA $0+362.14$ sampai STA $0+908.82$ sehingga didapatkan panjang lengkung adalah $547.79 \mathrm{~m}$.

Jarak pandang henti yang terdapat pada Tabel 7 lebih kecil dari pada panjang lengkung vertikal sebesar $547.79 \mathrm{~m}$. Berdasarkan Tabel 7 didapatkan bahwa panjang lengkung 
vertikal dapat dilalui dengan aman oleh pengemudi sampai pada kecepatan 70 $\mathrm{km} / \mathrm{jam}$. Lengkung vertikal yang dibutuhkan pada kecepatan $70 \mathrm{~km} / \mathrm{jam}$ membutuhkan lengkung yang lebih panjang karena semakin cepat kendaraan melaju, semakin panjang jarak pandang henti yang dibutuhkan. Koordinasi alinyemen merupakan bentuk koordinasi elemen - elemen jalan antara alinyemen horisontal, alinyemen vertikal dan potongan melintang jalan sehingga memudahkan pengemudi mengemudikan kendaraanya dengan aman dan nyaman.

Koordinasi alinyemen diperlukan ketika elemen - elemen jalan tidak dapat dipisahkan. Berdasarkan Gambar 17 titik tinjauan berada pada Sta $0+310$ dari arah Bogor menuju Leuwiliang. Lokasi tersebut merupakan lokasi yang terdapat tikungan pertama dan perubahan kelandaian.

Pandangan pengemudi tidak terhalang oleh perubahan alinyemen yang tedapat di depannya. Koordinasi alinyemen sesuai dengan peraturan yang berlaku. Hal tersebut dikarenakan antara alinyemen horisontal dan alinyemen vertikal yang berhimpit dan tidak terdapat blank spot atau area hitam pada daerah yang tidak dilihat oleh pengendara (Dirjen BM 1997).

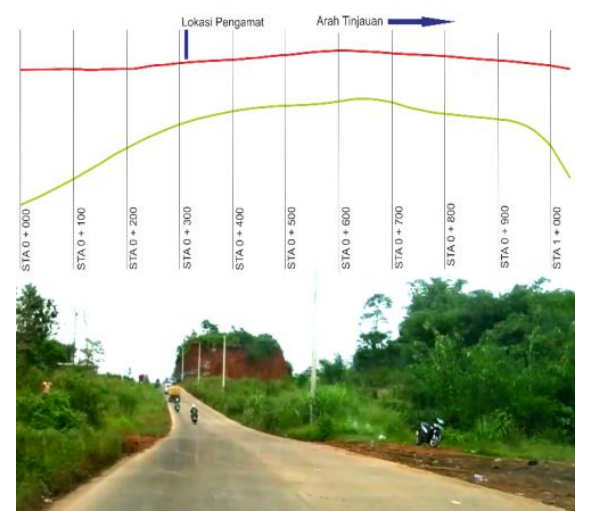

Gambar 17. Koordinasi alinyemen

\section{Perlengkapan Jalan}

Rambu lalu lintas berguna untuk memberitahukan informasi mengenai bahaya, larangan, perintah dan petunjuk kepada pengemudi. Rambu yang terpasang di jalan lingkar leuwi liang adalah rambu simpang empat dan rambu menurun. Rambu simpang empat dan rambu menurun merupakan rambu peringatan. Penempatan rambu peringatan berdasarkan Tata Cara Pemasangan Rambu dan Marka Jalan Perkotaan (Dirjen BM 1991), jarak rambu peringatan dengan kecepatan rencana kurang dari $60 \mathrm{~km} / \mathrm{jam}$ ditempatkan dengan jarak minimum 50 $m$ sebelum adanya bahaya. Penempatan rambu disisi jalan berjarak $60 \mathrm{~cm}$ dari tepi jalan. Ketinggian daun rambu yang ditempatkan pada sisi jalan berjarak minimal $175 \mathrm{~cm}$ dan maksimal $265 \mathrm{~cm}$.

Tabel 7. Perbandingan panjang minimum lengkung vertikal dengan panjang lengkung eksisting

\begin{tabular}{cccccccc}
\hline $\begin{array}{c}\text { Vr } \\
(\mathbf{k m} / \mathbf{j a m})\end{array}$ & $\begin{array}{c}\mathbf{S} \\
(\mathbf{m})\end{array}$ & $\begin{array}{c}\mathbf{D 1} \\
(\mathbf{m})\end{array}$ & $\begin{array}{c}\mathbf{D} 2 \\
(\mathbf{m})\end{array}$ & $\begin{array}{c}\mathbf{D} \\
(\mathbf{m})\end{array}$ & $\begin{array}{c}\text { L Hitung } \\
(\mathbf{m})\end{array}$ & $\begin{array}{c}\text { Lmin } \\
(\mathbf{m})\end{array}$ & $\begin{array}{c}\text { L Eksising } \\
(\mathbf{m})\end{array}$ \\
\hline 30 & 31.17 & & & & 35.44 & 2.4 & \\
40 & 46.15 & & & & 77.68 & 5.26 & \\
50 & 63.43 & & & & 146.71 & 9.93 & 547.79 \\
60 & 82.99 & 6.84 & -7.93 & 14.77 & 251.2 & 17.01 & \\
70 & 104.86 & & & & 400.96 & 27.15 & \\
80 & 129.01 & & & & 606.99 & 41.1 & \\
\hline
\end{tabular}




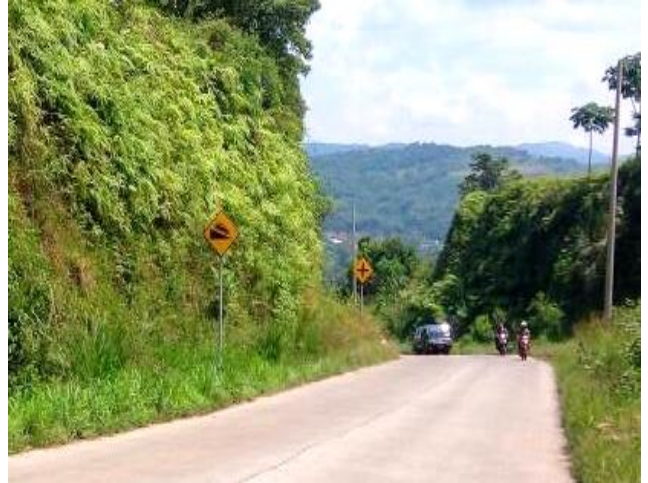

Gambar 18. Kondisi rambu dan marka Jalan Lingkar Leuwiliang

Penempatan rambu simpang empat terletak pada titik Sta 0+851.01. Rambu simpang empat berjarak $60 \mathrm{~m}$ dari persimpangan. Rambu simpang empat berjarak $72 \mathrm{~cm}$ dari tepi jalan. Tinggi daun rambu simpang empat dari tepi jalan adalah $184 \mathrm{~cm}$. Rambu menurun terletak pada Sta 0+919.73. Rambu menurun berjarak 61 meter dari permulaan menurun. Jarak rambu menurun sampai tepi jalan berjarak 78 $\mathrm{cm}$. Tinggi daun rambu dari tepi jalan berjarak $180 \mathrm{~cm}$. Berdasarkan Tata Cara Pemasangan Rambu dan Marka Jalan Perkotaan pemasangan rambu simpang empat dan rambu menurun sudah sesuai dengan pedoman yang berlaku (Dirjen BM 1991).

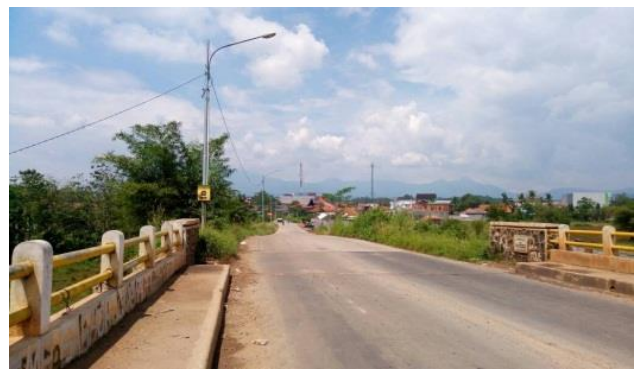

Gambar 19. Penerangan jalan pada Jalan Lingkar Leuwiliang

Marka jalan tidak terdapat pada Jalan Lingkar Leuwiliang. Hal tersebut dapat dilihat pada Gambar 20. Jalan tersebut dibatasi oleh pertemuan lapisan perkerasan dengan lapisan tanah pada jalan yang ditutupi oleh rumput. Timbulnya rumput - rumput tersebut akan membahayakan pengemudi jika menepi akibat kondisi darurat pada sisi jalan tersebut.

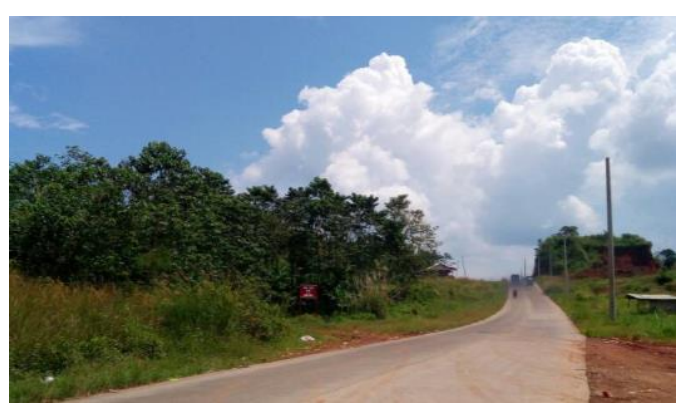

Gambar 20. Kondisi tiang listrik

Penerangan jalan umum (PJU) merupakan alat bantu penerangan pada jalan berupa lampu yang terpasangpada tiang. PJU membantu pengemudi untuk melihat jalan pada malam hari ataupun ketika jarak pandang sangat minim akibat faktor - faktor alam maupun buatan. Pemasangan PJU disesuaikan dengan kondisi jalan dan lingkungannya.

Tabel 8. Kondisi penerangan jalan

\begin{tabular}{cccc}
\hline $\begin{array}{c}\text { Tiang } \\
\text { Ke- }\end{array}$ & PJU & $\begin{array}{c}\text { Jenis } \\
\text { Lampu }\end{array}$ & Lokasi \\
\hline 1 & Ada & LED & $0+006.80$ \\
2 & Ada & LED & $0+044.29$ \\
3 & Ada & LED & $0+081.40$ \\
4 & Ada & LED & $0+120.94$ \\
5 & Ada & LED & $0+163.84$ \\
6 & Ada & LED & $0+199.12$ \\
7 & Tidak ada & & $0+241.76$ \\
8 & Tidak ada & & $0+287.31$ \\
9 & Tidak ada & & $0+330.61$ \\
10 & Tidak ada & & $0+373.50$ \\
11 & Tidak ada & & $0+422.69$ \\
12 & Tidak ada & & $0+477.56$ \\
13 & Tidak ada & & $0+534.18$ \\
14 & Tidak ada & & $0+584.13$ \\
15 & Tidak ada & & $0+634.18$ \\
16 & Tidak ada & & $0+684.74$ \\
\hline
\end{tabular}




\begin{tabular}{|c|c|c|c|}
\hline $\begin{array}{l}\text { Tiang } \\
\text { Ke- }\end{array}$ & PJU & $\begin{array}{c}\text { Jenis } \\
\text { Lampu }\end{array}$ & Lokasi \\
\hline 17 & Tidak ada & & $0+733.03$ \\
\hline 18 & Tidak ada & & $0+778.29$ \\
\hline 19 & Tidak ada & & $0+825.93$ \\
\hline 20 & Tidak ada & & $0+880.42$ \\
\hline 21 & Tidak ada & & $0+916.35$ \\
\hline 22 & Tidak ada & & $0+954.58$ \\
\hline
\end{tabular}

Lampu PJU pada Jalan Lingkar Leuwiliang terdapat 6 buah. Lampu PJU tersebut berupa LED yang menggunakan sumber listrik dari jaringan kabel yang berada pada daerah tersebut dan terletak pada tiang 1 yang terletak pada STA 0+006.80sampai tiang ke-6 pada titik STA 0+199.12. PJU yang terpasang menggunakan lampu LED dengan jarak rata - rata $38.38 \mathrm{~m}$. Sedangkan terdapat tiang listrik yang tidak digunakan sama sekali pada titik STA 0+241.76 sampai titik STA 0+954.58.

\section{Rekomendasi Perbaikan Geometri dan Perlengkapan Jalan}

Berdasarkan hasil evaluasi geometri jalandengan RSNI T-14-2004 (BSN 2004) dan Pedoman Jalan (Dirjen BM 1997) serta peraturan yang digunakan sebagai batasan evaluasi perlengkapan jalan adalah Pedoman No. 01/P/BNKT/1991 (Dirjen BM 1991) dan SNI 7391:2008 (BSN 2008) kondisi geometrik dan perlengkapan jalan pada Jalan Lingkar Leuwiliang belum memenuhi standar pedoman yang beralaku. Perbaikan geometrik pada bagian alinyemen horisontal pada jalan Lingkar Leuwiliang yaitu daerah bebas samping pada tikungan ke-4. Hal tersebu dikarenakan daerah bebas samping eksisting pada jalan sebesar 3 $\mathrm{m}$ lebih kecil dari nilai minimum yang dibutuhkan yaitu sebesar $3.04 \mathrm{~m}$ pada kecepatan yang dibatasi yaitu $50 \mathrm{~km} /$ jam. Kondisi sisi dalam tikungan berupa tebing yang diselimuti tanaman liar perlu dilakukan pembersihan agar daerah bebas samping pada tikungan ke-4 dapat memenuhi nilai minimum yang dperlukan.

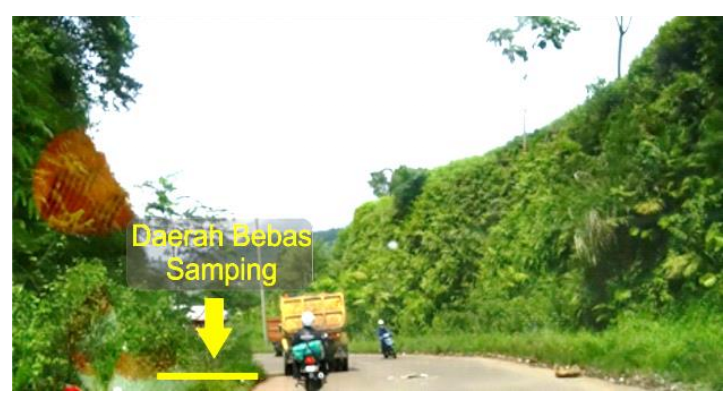

Gambar 21. Daerah bebas samping pada tikungan ke-4

Bagian pada alinyemen vertikal yang tidak memenuhi standar yaitu pada kelandaian bagian menanjak pada segmen 2 (14.21\%), segmen 4 (10.94\%), segmen $13(9.01 \%)$ dan segmen $14(9.19 \%)$ dan kelandaian bagian menurun pada segmen 26 (9.20\%), segmen 27 (9.20\%), segmen 28 (9.49\%), segmen 29 (12.15\%), segmen $30(19.36 \%)$ dan segmen 31 $(9.55 \%)$. kelandaian yan tidak sesuai dengan pedoman tersebut dapat menyebabkan perlambatan sementara yang tidak mengganggu lalu lintas yang ada. Perlambatan sementara tersebut dapat teratasi karena jarak kritis pada masing - masing kelandaian di bawah batas maksimal yang berlaku.

Marka jalan perlu dibuat agar dapat memberikan info kepada pengemudi batasan - batasan yang ada pada jalan. Marka jalan dibuat bedasarkan jarak pandang henti dan jarak pandang mendahului. Jarak pandang henti diasumsikan bahwa tinggi penemudi melihat jalan adalah $105 \mathrm{~cm}$ kemudian halangan yang berada didepannya memiliki tinggi 15 $\mathrm{cm}$ yang keduanya diukur dari permukaan jalan. Jarak pandang mendahului diasumsikan bahwa tinggi 
penemudi melihat jalan adalah $105 \mathrm{~cm}$ kemudian halangan yang berada didepannya memiliki tinggi $105 \mathrm{~cm}$ yang keduanya diukur dari permukaan jalan. Kecepatan yang menjadi acuan dalam disain marka jalan adalah 50 km/jam. Berdasarkan Tabel II.10 jarak pandang henti dan Tabel II.11 jarak pandang mendahului dalam Tata Cara Perencanaan Geometrik Jalan Antar Kota jarak pandang henti yang digunakan adalah $55 \mathrm{~m}$ dan jarak pandang mendahului adalah $250 \mathrm{~m}$ (Dirjen BM 1997).

Disain marka jalan pada Jalan Lingkar Leuwiliang berupa marka membujur. Marka membujur berupa garis utuh berfungsi untuk menandakan tepi jalur lalu lintas. Marka membujur garis utuh juga digunakan pada jalan yang memiliki jarak padang yang terbatas. Penempatan marka jalan dibuat dari awal permulaan jalan sampai akhir permulaan jalan. Adapun pada pembahasan ini terbatas pada jarak jalan yang terukur.
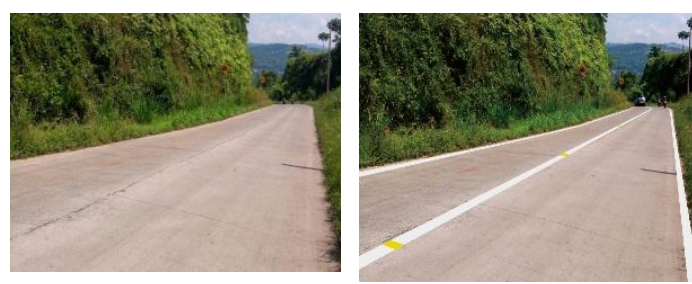

Gambar 22. Rekomendasi marka melintang garis utuh jalan

Marka membujur garis putuh dibuat pada tepi perkerasan beton jalan. Marka membujur garis utuh dibuat dengan lebar $0.10 \mathrm{~m}$. Marka membujur garis utuh dibuat pada tepi jalan dari titik awal jalan sampai titik Sta 0+974.5. Pemisah jalan dibuat dengan marka membujur garis putus - putus yang dibuat pada Sta 0+000 sampai Sta $0+200$. Kemudian marka membujur garis utuh dibuat dari Sta $0+200$ sampai persimpangan empat pada titik 0+974.5. Marka membujur garis utuh dibuat karena jarak pandang mendahului tidak memenuhi kebutuhan sepanjang $250 \mathrm{~m}$. Contoh rekomendasi marka jalan dapat dilihat pada Gambar 24 yang dilihat dari Sta $0+851.01$ Marka membujur garis utuh tambahkan paku jalan berbentuk persegi dengan ukuran 0.1 x $0.1 \mathrm{~m}^{2}$. Warna lampu yang dipantulkan berwarna kuning yang terbuat dari sepihan kaca halus. Paku jalan berfungsi untuk memberi informasi batas jalan kepada pengemudi.

Cat yang digunakan berjenis cat thermoplastik tipe $\mathrm{F}$ dengan waktu pengeringan berkisar 3 menit sampai 6 menit dengan dipanasi sampai $51.5 \pm$ $2.5{ }^{0} \mathrm{C}$ pada mesin cat. Pemilihan cat tipe $\mathrm{F}$ dikarenakan Cat tipe $\mathrm{F}$ terdiri dari medium soya oil linseed alkyd resin, chlorinated rubber dan chlorinated parafin teknis dengan perbandingan berat $1.03: 1.03: 1.00$. Kemudian ditambahan bahan metyl keton (MEK) sebagai pelart utama sesuai spesifikasi ASTM D-740 (BSN 1998).

Pemasangan Penerangan Jalan Umum (PJU) pada Jalan Lingkar Leuwiliang harus dilanjutkan sampai jalan memenuhi standar yang berlaku. Pemasangan PJU dilakukan pada tiang listrik yang terpasang sepanjan jalan yang tidak terdapat PJU.Hal tersebut dilakukan agar menghemat penggunaan bahan serta untuk kesan pada jalan. Lokasi tiang listrik yang direkomendasikan untuk dipasang lampu PJU pada Jalan Lingkar Leuwiliang tersaji pada Tabel 9.

Berdasarkan SNI no. 7391 tahun 2008 tenang Spesifikasi Penerangan di Kawasan Perkotaan, pemasangan PJU menggunakan jenis lampu gas sodium tekanan tinggi (SON) dengan daya 100 watt dengan tinggi pemasangna lampu $6 \mathrm{~m}$ dari tanah. Pemilihan lampu tersebut karena lampu SON dapat digunakan untuk jalan kolektor, 
efisiensi tinggi, umur sangat panjang, ukuran lampu kecil sehingga mudah untuk mengontrol cahayannya dan lampu dengan tipe ini banyak direkomendasikan untuk digunakan sebagai PJU. Rumah lampu yang digunakan memakai rumah lampu tipe B. Rumah lampu tersebut disambung dengan batang alumunium dengan panjang $2.3 \mathrm{~m}$. Batang alumunium tersebut ditekuk sebesar $105^{0}$ sehingga kemiringn lampu terhadap jalan adalah $15^{0}$.

Tabel 9. Penambahan penerangan jalan

\begin{tabular}{cccc}
\hline $\begin{array}{c}\text { Lampu } \\
\text { Ke- }\end{array}$ & $\begin{array}{c}\text { Jenis } \\
\text { Lampu }\end{array}$ & $\begin{array}{c}\text { Jarak } \\
\text { Antar } \\
\text { Lampu } \\
(\mathrm{m})\end{array}$ & Lokasi \\
\hline 1 & LED & 6.801 & $0+006.8$ \\
2 & LED & 37.492 & $0+044.29$ \\
3 & LED & 37.106 & $0+081.39$ \\
4 & LED & 39.540 & $0+120.94$ \\
5 & LED & 42.905 & $0+163.84$ \\
6 & LED & 35.276 & $0+199.12$ \\
7 & SON 100W & 42.640 & $0+241.76$ \\
8 & SON 100W & 45.550 & $0+287.31$ \\
9 & SON 100W & 43.300 & $0+330.61$ \\
10 & SON 100W & 42.890 & $0+373.5$ \\
11 & SON 100W & 49.190 & $0+422.69$ \\
12 & SON 100W & 54.870 & $0+477.56$ \\
13 & SON 100W & 56.620 & $0+534.18$ \\
14 & SON 100W & 49.950 & $0+584.13$ \\
15 & SON 100W & 50.050 & $0+634.18$ \\
16 & SON 100W & 50.560 & $0+684.74$ \\
17 & SON 100W & 48.290 & $0+733.03$ \\
18 & SON 100W & 45.260 & $0+778.29$ \\
19 & SON 100W & 47.640 & $0+825.93$ \\
20 & SON 100W & 54.490 & $0+880.42$ \\
21 & SON 100W & 35.930 & $0+916.35$ \\
22 & SON 100W & 38.230 & $0+954.58$ \\
\hline & & & \\
& & &
\end{tabular}

Penggunaan lampu SON $100 \mathrm{~W}$ dikarenakan untuk mengefisienkan penggunaan tiang yang terdapat pada tiang ke-7 sampai tiang ke-22. Jarak rata - rata antar tiang adalah $47.21 \mathrm{~m}$
(BSN 2008). Jarak rata - rata tersebut dibulatkan ke atas sehingga angka yang diambil sebagai acuan dalam pemilihan lampu penerangan jalan adalah $48 \mathrm{~m}$.

\section{SIMPULAN DAN SARAN}

\section{Simpulan}

Jalan Lingkar Leuwiliang merupakan jalan kolektor yang memindahkan arus kendaraan besar yang melalui Pasar Leuwiliang. Jalan lingkar Leuwiliang berada pada daerah kepadatan penduduk yang rendah sehingga kecepatan maksimal yang diatur $50 \mathrm{~km} / \mathrm{jam}$. Berdasarkan kecepatan tersebut pada alinyemen horisontal jarak pandang bebas daerah bebas samping terdapat bagian yang tidak memenuhi kriteria pedoman yang berlaku yaitu daerah bebas samping pada tikungan ke-4 sebesar 3 m kurang dari 3.04. Kelandaian pada alinyemen vertikal yang melebihi $9 \%$ terjadi pada segmen 2, segmen 4, segmen 13, segmen 14, segmen 26, segmen 27, segmen 28, segmen 29 dan segmen 30. Marka jalan yang tidak terdapat pada Jalan Lingkar Leuwiliang. Marka jalan kemudia didisain menggunakan marka membujur garis utuh pada tepi dan pembatas jalan dengan paku jalan. Lampu penerangan pada tiang ke-7 sampai tiang ke-22 tidak ada. Lampu penerangan jalan yang didisain menggunakan jenis SON $100 \mathrm{~W}$ denga tinggi $6 \mathrm{~m}$ dari permukaan tanah pada tiang - tiang yang tidak terdapat lampu penerangan.

\section{Saran}

Perlu studi khusus mengenai kapasitas Jalan Lingkar Leuwiliang, khususnya dalam pelayanan volume kapasitas jalan agar dapat menentukan lebar jalan yang ideal pada Jalan Lingkar Leuwiliang. Studi mengenai Damija (Daerah Milik Jalan), Damaja 
(Daerah Manfaat Jalan) dan Dawasja (Daerah Pengawasan Jalan)agar dapat menentukan efektifitas pelayanan jalan sehingga nyaman bagi pengemudi. Perlu perhitungan volume timbunan dan galian untuk melakukan perubahan alinymen agar sesuai dengan pedoman dan peraturan yang berlaku. Perlu juga adanya studi dan penelitian lebih lanjut mengenai biaya yang dikeluarkan dalam penggunaan lampu gas sodium tekanan tinggi (SON) dengan daya 100 watt dengan lampu LED agar lampu yang digunakan ekonomis dan tepat guna.

\section{DAFTAR PUSTAKA}

[Bakosurtanal] Badan Koordinasi Survei dan Pemetaan Nasional. 2007. Penataan Ruang Kawasan Jakarta, Bogor, Depok,Tangerang, Bekasi, Puncak Dan Cianjur. Jakarta (ID):Badan Koordinasi Survei dan Pemetaan Nasional.

[BSN] Badan Standardisasi Nasional. 1998. Spesifikasi Campuran Cat Marka Jalan Siap Pakai Warna Putih dan Kuning No. SNI 064825-1998. Jakarta (ID): Badan Standardisasi Nasional.

[BSN] Badan Standardisasi Nasional Indonesia. 2004. Geometri Jalan Perkotaan No. RSNI T-14-2004. Jakarta (ID): Badan Standardisasi Nasional.

[BSN] Badan Standardisasi Nasional. 2008. Spesifikasi Penerangan Jalan di Kawasan Perkotaan No. SNI 7391:2008. Jakarta (ID) : Badan Standardisasi Nasional.

Hendarsin SL. 2000. Penuntun Praktis Perencanaan Teknik Jalan Raya. Bandung (ID) : Jurusan Teknik Sipil Politeknik Negeri Bandung. Hermansyah T, Isya M, Saleh SM. 2015. Keserasian rambu dan marka terhadap geometrik jalan pada jalan antar kota (studi kasus Jalan Banda Aceh Km.77 Batas Pidie). Jurnal teknik Sipil. 4(4) : $232-253$.

[KemenHub] Kementrian Perhubungan. 2015. Tata Cara Penetapan Batas Kecepatan. Peraturan Mentri Perhubungan Republik Indonesia No. PM 111 tahun 2015. Jakarta (ID) : Kementrian Perhubungan.

Made ID, Widianty D. 2014. Analisis jarak pandang henti sebagai elemen geometrik pada beberapa tikungan ruas Jalan MataramLembar. Jurnal Penelitian UNRAM. 18(2) : 40 - 48.

Manggala R, Angga J, Purwanto D, Indriastuti AK. 2015. Studi kasus faktor penyebab kecelakaan lalu lintas pada tikungan tajam. Jurnal Karya Teknik Sipil. 4(4). $426-470$.

Munawar A. 2006. Manajemen Lalu Lintas Perkotaan.Yogyakarta (ID) : Beta Offset

Nugroho. 2012. Analisis Pengaruh Kecepatan Kendaraan Terhadap Umur Rencana Jalan Dengan Menggunakan Metode Analitis (Studi Kasus Ruas Jalan Rembang - Bulu). [Skripsi]. Fakultas Teknik Universitas Muhammadiyah Surakarta.

Oglesby CH, Hicks RG. 1990. Teknik Jalan Raya. Setianto P, penerjemah. Jakarta (ID) : Erlangga. Terjemahan dari : Highway Engineering.

Pandey S, Lalamentik L. 2014. Kelas jalan untuk angkutan barang. Jurnal Tekno Sipil.12(60) : 27 37.

[PRI] Pemerintah Republik Indonesia . 2006.JalanPeraturan Pemerintah No. 34 tahun 2006. Jakarta (ID) : Pemerintah Republik Indonesia. 
[PRI] Pemerintah Republik Indonesia. 2009.Lalu Lintas dan Angkutan Jalan.Undang - undang Republik Indonesia No. 22 Tahun 2009. Jakarta (ID) : Pemerintah Republik Indonesia.

Pribadi D, Paransa MJ, Sednow TK, Undap LJ . 2013. Tinjauan geometrik jalan pada ruas Jalan Airmadidi-Tondano menggunakan alat bantu GPS. Jurnal Sipil Statik. 1(7) : 49 505.

Purwanto D, Indriastuti AK, Basuki KH. 2015. Hubungan antara kecepatan dan kondisi geometrik jalan yang berpotensi menyebabkan kecelakaan lalu lintas pada tikungan. Jurnal Media Komunikasi Teknik Sipil. 21(2) : $83-90$.

Sendow TK, Jefferson L. 2012. Studi pemetaan peta kota (studi kasus Kota Manado). Jurnal Ilmiah Media Engineering. 2(1) : 35 46.
Setyowati S, Setyawan A, Djumari. 2014. Evaluasi kondisi Jalan Salatiga-Sruwen KM. SMG $57+050$ - KM. SMG 59+050 terhadap katagori resiko terjadinya kecelakaan. e-Jurnal Matriks Teknik. 2(1) : 91 - 99.

Sukirman S. 1999. Dasar-Dasar Perencanaan Geometrik Jalan. Bandung (ID) : Nova.

Sulistio H. 1997. Hubungan antara kelengkungan jalan dan kecepatan operasi kendaraan (studi kasus pada beberapa ruas jalan di Malang). Jurnal Teknik. 4(8): 854-895

Suwardo, Handoyo I. 2016. Perancangan Geometrik Jalan Standar dan Dasar - dasar Perancangan. Yogyakarta (ID) : Gajah Mada University Press.

Utami MS, Sukirman S. 2016. Kajian kelengkapan perlengkapan jalan pada Jalan Pelajar Pejuang Bandung. Jurnal Online Institut Teknologi Nasional. 20(10) : 1 12. 
